Article

\title{
Early Season Foliar Iron Fertilization Increases Fruit Yield and Quality in Pomegranate
}

\author{
Sohrab Davarpanah ${ }^{1}$, Ali Tehranifar ${ }^{1, *}$, Mahvash Zarei ${ }^{1}$, Mehdi Aran ${ }^{2}$, \\ Gholamhossein Davarynejad ${ }^{1}$ and Javier Abadía ${ }^{3, *}$ (D) \\ 1 Department of Horticultural Science and Landscape, Ferdowsi University of Mashhad, \\ Mashhad 9177948974, Iran \\ 2 Department of Horticultural Science, College of Agriculture, University of Zabol, Zabol 53898615, Iran \\ 3 Department of Plant Nutrition, Estación Experimental de Aula Dei (EEAD-CSIC), 50059 Zaragoza, Spain \\ * Correspondence: tehranifar@um.ac.ir (A.T.); jabadia@eead.csic.es (J.A.)
}

Received: 4 May 2020; Accepted: 10 June 2020; Published: 12 June 2020

check for updates

\begin{abstract}
Early season foliar fertilization with different nutrients is a promising tool in pomegranate grown in poor, high $\mathrm{pH}$ soils. The effects of foliar fertilization with $\mathrm{FeSO}_{4}$ and the synthetic chelate Fe(III)-EDDHA (Fe(III)-ethylendiaminedi(o-hydroxyphenylacetate)) on fruit yield and physicochemical characteristics were assessed in a two-season field trial. Fertilizers were sprayed at full bloom and one month later, using Fe concentrations of 1.3 and $2.6 \mathrm{mM}$ for $\mathrm{FeSO}_{4}$ and 1.1 and $2.1 \mathrm{mM}$ for the Fe-chelate. Both doses of $\mathrm{FeSO}_{4}$ and the higher chelate dose increased leaf Fe concentrations and fruit yield, with the best results being observed with $2.6 \mathrm{mM} \mathrm{FeSO}_{4}(20-31 \%$ increases in yield). On the other hand, leaf $\mathrm{N}, \mathrm{P}, \mathrm{K}, \mathrm{Ca}$, and $\mathrm{Mn}$ concentrations were not affected by foliar Fe fertilization. The only treatment that increased the number of fruits per tree, aril juice content and juice total soluble solids and decreased juice total acidity in both seasons was $2.6 \mathrm{mM}$ $\mathrm{FeSO}_{4}$. Both $\mathrm{FeSO}_{4}$ doses caused consistent increases in the maturity index and total sugars in juice, along with minor decreases in juice total phenolic compounds. The antioxidant activity in juice was slightly decreased by $2.6 \mathrm{mM} \mathrm{FeSO}_{4}$. In conclusion, early season foliar Fe fertilization had positive effects on pomegranate yield and quality, with $\mathrm{FeSO}_{4}$ being better than Fe(III)-EDDHA.
\end{abstract}

Keywords: Punica granatum L.; foliar fertilization; iron chlorosis; iron deficiency; fruit quality

\section{Introduction}

Pomegranate (Punica granatum L.; Punicaceae) is a fruit tree grown in a wide range of soils in subtropical and tropical regions, including Mediterranean, Caucasian and Asian countries [1]. In Iran, the cultivation area in 2016 was ca. 75,000 ha and the total annual production was more than 1.1 million ton [2] Pomegranate fruits are consumed fresh or processed in a variety of forms, and are widely thought to promote human health because of the high antioxidant content [3].

Fertilizers are crucial for fruit tree production because the plant nutritional status affects vegetative growth, flowering, fruit set and fruit retention and has a marked effect on fruit quality and yield $[4,5]$. Macronutrients and micronutrients are usually acquired from the soil by roots, but both types of nutrients can be also supplied directly to plants via foliar fertilization. This practice minimizes fertilizer and water inputs, and is increasingly used in arid and semiarid regions to correct micronutrient deficiencies [6]. Foliar fertilization has been shown to enhance grain metal contents in cereals [7] and to improve plant nutritional status [8] and fruit set [6] in tree crops. However, crop responses to foliar fertilization largely depend on experimental conditions and plant species $[6,8]$.

Iron is very abundant in most soils (ca. 5\% of the Earth's crust), but it is mainly present in chemical forms that are unavailable for plants in neutral and alkaline soils [9]. Therefore, Fe deficiency 
(commonly referred to as Fe chlorosis, due to the yellowish color of the leaves) is widespread in fruit crops grown in calcareous soils and is a yield limiting factor in many agricultural areas worldwide because of the decreases in photosynthetic activity and crop yield [10]. The correction of Fe deficiency in fruit trees is generally done using soil-applied synthetic Fe(III)-chelates, which have a good chemical stability at the $\mathrm{pH}$ of calcareous soils [11], but foliar fertilization with Fe and solid trunk implants containing Fe compounds are also used [12,13].

Recent studies have shown that in pomegranate trees grown in high $\mathrm{pH}$, nutrient-poor soils in northeastern Iran, early season foliar fertilization carried out at the flowering stage and shortly afterwards was able to improve fruit set and consequently fruit yield. This occurred when the fertilizer contained Zn and B [14] and N [15], but not when it contained Ca, whereas the Ca fertilizer was effective in reducing fruit cracking [16]. These experiments indicated that the flowers of pomegranate, which are quite large and fleshy [17], constitute a promising way of entry into the tree for essential nutrients such as Zn, B and N. On the basis that an Fe shortage can be also crucial at the nutrient-demanding flowering stage, this study was aimed to test the hypothesis that early season foliar applications of Fe fertilizers can also improve pomegranate fruit yield and quality.

\section{Materials and Methods}

\subsection{Plant Material, Experimental Site and Fertilizer Treatments}

The experiment was performed in the years 2014 and 2015 in a commercial pomegranate (Punica granatum L. cv. Ardestani) orchard (Figure S1 in the Supplementary File). This orchard is located in northeastern Iran (latitude $35^{\circ} 1^{\prime} 24.33^{\prime \prime} \mathrm{N}$, longitude $58^{\circ} 50^{\prime} 19.61^{\prime \prime} \mathrm{E}$; altitude $967 \mathrm{~m}$ ) on coarse-loamy soil ( $64 \%$ sand, $12 \%$ clay and $24 \%$ silt) over fragmental, mixed and thermic Xeric Torriorthents soil, with a $\mathrm{pH}$ of 8.1 (in water) and an electrical conductivity (EC) of $9.4 \mathrm{dS} \mathrm{m}^{-1}$. The cultivar Ardestani is an Iranian, late ripening, sweet-sour pomegranate; it has a rounded shape, skin and arils are red, and is usually consumed fresh. The region is arid with a mean annual temperature of $14.8^{\circ} \mathrm{C}$ and annual mean rainfall of $248 \mathrm{~mm}$. Trees were eight years old, had three trunks and a height of approximately $2.5-3.0 \mathrm{~m}$, and were planted on a $3 \times 5 \mathrm{~m}$ frame $\left(667 \mathrm{trees} \mathrm{ha}^{-1}\right)$. The orchard was drip-irrigated and fertilized in winter with $100 \mathrm{~kg} \mathrm{ha}^{-1}$ each of urea, $\mathrm{K}_{2} \mathrm{SO}_{4}$ and $\mathrm{Ca}\left(\mathrm{H}_{2} \mathrm{PO}_{4}\right)$.

The trial was performed with a completely randomized block design, using five fertilization treatments and four replications per treatment and year (each replicate was performed in an individual tree). Two commercial (liquid) Fe fertilizers were used: a product containing $\mathrm{FeSO}_{4}$ and the chelate $\mathrm{Fe}(\mathrm{III})$-EDDHA (Fe(III)-ethylendiaminedi(o-hydroxyphenylacetate)). The $\mathrm{FeSO}_{4}$ fertilizer used contained $12 \% \mathrm{Fe}(\mathrm{II})$ and a small amount of Fe nanoparticles and microparticles $(<0.1$ and $0.1-2 \mu \mathrm{m}$, respectively). Two particles $(1.0-1.3 \mu \mathrm{m}$ ) were analyzed by scanning electron microscopy coupled to X-ray dispersion (SEM-EDX) and were found to contain only Fe (Figure S2 in the Supplementary File), likely in the form of Fe oxide. Fertilizer concentrations used were 72 and $144 \mathrm{mg} \mathrm{Fe} \mathrm{L}^{-1}$ in the case of $\mathrm{FeSO}_{4}$ (nFe1 and $\mathrm{nFe} 2$, respectively; equivalent to 1.3 and $2.6 \mathrm{mM} \mathrm{Fe}$, respectively), and 60 and $120 \mathrm{mg}$ $\mathrm{Fe} \mathrm{L}^{-1}$ in the case of $\mathrm{Fe}(\mathrm{III})-\mathrm{EDDHA}$ ( $\mathrm{cFe} 1$ and $\mathrm{cFe} 2$, respectively; equivalent to 1.1 and $2.1 \mathrm{mM} \mathrm{Fe}$, respectively). Control trees were sprayed with water only. Fertilizer formulations were prepared by diluting the commercial products with water. Foliar fertilization was carried out first at full bloom (on 12 May 2014 and 26 April 2015) and again one month later. Trees sampled in 2015 were different from those used in 2014 and had not been fertilized with Fe in 2014. Pomegranate flowers are large and grow in clusters, with flowering occurring in three waves spaced 10 to 15 days from each other $[17,18]$, and the first wave is the one contributing most to fruit yield [1]. In pomegranate, leaves are already developed at the full bloom stage. Each fertilizer application was made with a total of $5.3 \mathrm{~L}$ tree $\mathrm{e}^{-1}$. The first fertilization event wet leaves, developed flowers of the first wave and buds, and the second fertilization event wet leaves, flowers of the third wave and small developing fruits. Total Fe doses were 382 or $763 \mathrm{mg} \mathrm{Fe}^{-1}$ free $\mathrm{FeSO}_{4}$ and 318 or $636 \mathrm{mg} \mathrm{Fe} \mathrm{tree}^{-1}$ for Fe(III)-EDDHA. 
One hundred leaves were taken from the midst of fruiting shoots (all around the canopy of the three trunks in each tree) on 11 August 2014 and 6 August 2015. Fruits were harvested on 22 October 2014 and 14 October 2015 (these harvest dates were based on general fruit appearance and fruit chemical properties).

\subsection{Concentrations of Macro- and Micro-Elements in Leaves}

Leaf macronutrient and micronutrient concentrations were determined in the first season at the University of Mashhad and in the second season at the EEAD-CSIC in Spain. In Iran, the analysis was carried out as described by Chapman and Pratt [19] by measuring total N, P, K and Ca using the Kjeldahl method, spectrophotometry, flame photometry and complexometry, respectively, and $\mathrm{Fe}, \mathrm{Zn}$ and $\mathrm{Mn}$ using flame atomic absorption spectrophotometry (FAAS). In Spain, samples were digested on a microwave device and analyzed for $\mathrm{K}$ by flame emission spectroscopy and for $\mathrm{Ca}, \mathrm{Mg}$, $\mathrm{Fe}, \mathrm{Mn}, \mathrm{Zn}$ and $\mathrm{Cu}$ by FAAS [20].

\subsection{Fruit Physical Properties}

Four fruits were selected randomly from each tree, and fruit weight was measured. Fruit diameter, length, fruit calyx diameter (the widest part of the calyx) and peel thickness were measured using a digital Vernier gauge. In order to determine peel weight and aril percentage of each fruit, fruits were peeled manually and the weight of total arils and peel was measured. The weight of 100 arils was determined and the juice was extracted from $100 \mathrm{~g}$ aril using a manual extractor. For all physical parameters, four replications per treatment and year were carried out. All measurements were made according to established methods [21,22].

\subsection{Fruit Chemical Properties}

In each tree, a total of 12 fruits were sampled ( 3 each in the four geographical orientations-North, South, East and West), the juice was extracted and the juice of three fruits was pooled to constitute a sample. All determinations were carried out with four replications per treatment and year as described in detail in previous studies [14-16]. Titratable acidity (TA) was measured by titration, expressing results as citric acid percentage. Total soluble solids (TSS, \%) were measured using a digital refractometer and the TSS/TA ratio was taken as the maturity index. Total phenolic content in juice was determined by the Folin-Ciocalteu method and antioxidant activity in juice was determined using DPPH (1,1-diphenyl-2-picrylhydrazyl), with results being expressed as antioxidant activities in \%. Total anthocyanins were estimated by the two-buffer $\mathrm{pH}$ differential method and results were expressed as mg cyanidin-3-glucoside per $100 \mathrm{~g}$ of juice. Total soluble sugar content was determined using anthrone and a glucose standard curve for quantification.

\subsection{Statistical Analysis}

The experimental design used was a randomized complete block design with four replications. All data were assessed by analysis of variance (ANOVA) using SAS base 9 software (SAS Institute Inc., Cary, NC, USA). Means were compared using Duncan's multiple range test at $p<0.05$.

\section{Results}

\subsection{Changes in Leaf Elemental Concentrations upon Foliar Fertilization with Iron Compounds}

The leaf Fe concentrations in untreated control trees in the summer of the two seasons studied were $108-118 \mathrm{mg} \mathrm{kg}^{-1}$ dry weight (DW) (Table 1). In spite of these relatively high leaf Fe concentrations, pomegranate tree leaves had Fe deficiency symptoms in the summer of both seasons (not shown). The average leaf $\mathrm{N}, \mathrm{P}, \mathrm{K}$ and Ca concentrations (in both seasons) were $1.79 \%, 0.10 \%, 0.89 \%$ and $2.40 \%$, respectively, and the average leaf $\mathrm{Mn}$ and $\mathrm{Zn}$ concentrations were 74 and $14 \mathrm{mg} \mathrm{kg}^{-1} \mathrm{DW}$, respectively (Table S1 in the Supplementary File). 
Foliar Fe fertilization led to significant increases in leaf Fe concentrations when compared with those in the unfertilized controls, the only exception being the lowest dose of chelate (cFe1; Table 1). Leaf concentrations after fertilization were 126-150 mg Fe kg${ }^{-1} \mathrm{DW}$ (increases of 17-27\%) for $\mathrm{FeSO}_{4}$ and 113-138 $\mathrm{mg} \mathrm{Fe} \mathrm{kg}^{-1} \mathrm{DW}$ (increases of 4-17\%) for Fe(III)-EDDHA. On the other hand, foliar Fe fertilization did not affect leaf N, P, K, Ca, Mn and Zn concentrations (Table S1 in the Supplementary File).

\subsection{Changes in Fruit Physical Characteristics upon Foliar Fertilization with Iron Compounds}

Foliar fertilization with Fe compounds significantly increased fruit yield in both seasons, with the only exception being the lowest dose of chelate (Table 1). Yield increases were $11-31 \%$ and $10-20 \%$ in 2014 and 2015, respectively. The magnitude of the increases in fruit yield depended on the specific treatment, and the increases were larger in 2014 than in 2015. Foliar Fe fertilization also led to increases in the number of fruits per tree with both doses of $\mathrm{FeSO}_{4}$ in 2014 and in the higher doses of both fertilizers in 2015; increases in the number of fruits per tree were 20-24\% and 9-16\% in 2014 and 2015, respectively, again depending on the treatment (Table 1). The highest fruit yield and number of fruits per tree were observed in trees treated with $2.6 \mathrm{mM} \mathrm{FeSO}_{4}$, whereas the lowest values were observed in unfertilized control trees. When comparing Fe products, $2.6 \mathrm{mM} \mathrm{FeSO}_{4}$ generally led to higher yields (17\% in 2014 and $9 \%$ in 2015) and number of fruits per tree (13\% in 2014) when compared with the higher dose of chelate. On the other hand, Fe foliar fertilization did not affect other fruit parameters, including weight, diameter, length and cracking (Table S2 in the Supplementary File).

The only treatment that significantly increased aril juice (in both years) was $2.6 \mathrm{mM} \mathrm{FeSO}$ (by 7-10\%) when compared to the unfertilized controls; in both years, the differences between the higher doses of both compounds were not statistically significant (Table 1). Iron fertilization had no effect on other parameters measured, including the weight of 100 arils, aril and peel percentages, aril/peel ratio, fruit peel thickness and calyx diameter (Tables S2 and S3 in the Supplementary File).

\subsection{Changes in Fruit Chemical Characteristics upon Foliar Fertilization with Iron Compounds}

The only Fe foliar fertilization treatment that increased TSS in fruit juice in both years was $2.6 \mathrm{mM}$ $\mathrm{FeSO}_{4}$, whereas the higher dose of chelate led to TSS increases only in 2015 (Table 2). The increases in TSS were always below $10 \%$. The largest TSS values (17.9-18.0\%) were obtained in trees treated with $2.6 \mathrm{mM} \mathrm{FeSO}_{4}$, whereas the lowest values (16.3-16.8\%) were observed in the unfertilized controls. The only foliar treatment that caused changes in the TA of fruit juice was $2.6 \mathrm{mM} \mathrm{FeSO}_{4}$, which decreased TA by $17 \%$ and $11 \%$ in 2014 and 2015, respectively, when compared with the unfertilized control (Table 2). Foliar fertilization with the two doses of $\mathrm{FeSO}_{4}$ led to significant increases in the maturity index in the two years studied (13-33\% and 11-21\% increases in 2014 and 2015, respectively, when compared with unsprayed trees), whereas the $2.1 \mathrm{mM}$ chelate also led to an increase in maturity index in 2015 (Table 2). 
Table 1. Effect of foliar fertilization with $\mathrm{FeSO}_{4}(\mathrm{nFe})$ and $\mathrm{Fe}(\mathrm{III})-\mathrm{EDDHA}$ (cFe) on pomegranate leaf Fe concentrations, fruit yield, number of fruits per tree and aril juice in 2014 and 2015.

\begin{tabular}{|c|c|c|c|c|c|c|c|c|}
\hline \multirow[t]{2}{*}{ Treatment } & \multicolumn{2}{|c|}{$\begin{array}{c}\text { Fe } \\
(\mathrm{mg} / \mathrm{kg})\end{array}$} & \multicolumn{2}{|c|}{$\begin{array}{c}\text { Yield } \\
\left.\text { (kg Tree }^{-1}\right)\end{array}$} & \multicolumn{2}{|c|}{ Fruits per Tree } & \multicolumn{2}{|c|}{$\begin{array}{l}\text { Aril Juice } \\
(\mathrm{mL})\end{array}$} \\
\hline & 2014 & 2015 & 2014 & 2015 & 2014 & 2015 & 2014 & 2015 \\
\hline Control & $108.3^{d}$ & $118.0^{\mathrm{c}}$ & $12.4^{\mathrm{c}}$ & $16.2^{c}$ & $45.5^{\mathrm{c}}$ & $55.3^{c}$ & $61.3^{b}$ & $62.5^{b}$ \\
\hline nFe1 & $126.4^{\mathrm{ab}}$ & $141.9^{a b}$ & $15.3^{\mathrm{a}}$ & $18.1^{\mathrm{ab}}$ & $54.5^{\mathrm{ab}}$ & $59.5^{\mathrm{abc}}$ & $62.0^{\mathrm{b}}$ & $65.3^{\mathrm{ab}}$ \\
\hline $\mathrm{nFe} 2$ & $128.8^{\mathrm{a}}$ & $150.0^{\mathrm{a}}$ & $16.2^{\mathrm{a}}$ & $19.5^{\mathrm{a}}$ & $56.3^{\mathrm{a}}$ & $64.0^{\mathrm{a}}$ & $67.4^{\mathrm{a}}$ & $66.9^{a}$ \\
\hline $\mathrm{cFe} 1$ & $113.0^{\mathrm{cd}}$ & $130.0^{b c}$ & $13.4^{b c}$ & $17.7^{\mathrm{bc}}$ & $48.8^{c}$ & $58.3^{b c}$ & $61.8^{\mathrm{b}}$ & $63.0^{\mathrm{b}}$ \\
\hline $\mathrm{cFe} 2$ & $119.1^{b c}$ & $137.5^{\mathrm{ab}}$ & $13.8^{\mathrm{b}}$ & $17.9^{b}$ & $50.0^{b c}$ & $60.3^{a b}$ & $64.9^{a b}$ & $63.9^{\mathrm{ab}}$ \\
\hline
\end{tabular}

$\mathrm{FeSO}_{4}$ was used at rates of $72(\mathrm{nF} 1)$ and $144(\mathrm{nF} 2) \mathrm{mg} \mathrm{Fe} \mathrm{L}^{-1}$ and Fe(III)-EDDHA was used at rates of 60 (cF1) and 120 (cF2) mg Fe $\mathrm{L}^{-1}$. In each column, means followed by the same letter were not significantly different $(p<0.05)$.

Table 2. Effect of foliar fertilization with $\mathrm{FeSO}_{4}$ (nFe) and Fe(III)-EDDHA (cFe) on pomegranate fruit total soluble solids (TSS), titratable acidity (TA), maturity index, total sugars, total phenols and antioxidant activity in 2014 and 2015.

\begin{tabular}{|c|c|c|c|c|c|c|c|c|c|c|c|c|}
\hline \multirow[t]{2}{*}{ Treatment } & \multicolumn{2}{|c|}{$\begin{array}{l}\text { TSS } \\
\text { (Brix) }\end{array}$} & \multicolumn{2}{|c|}{$\begin{array}{l}\text { TA } \\
(\%)\end{array}$} & \multicolumn{2}{|c|}{$\begin{array}{l}\text { Maturity Index } \\
\text { (TSS/TA Ratio) }\end{array}$} & \multicolumn{2}{|c|}{$\begin{array}{l}\text { Total Sugars } \\
\left(\mathrm{g} 100 \mathrm{~g}^{-1} \text { FW) }\right.\end{array}$} & \multicolumn{2}{|c|}{$\begin{array}{l}\text { Total Phenolics } \\
\left.\text { (mg } 100 \mathrm{~g}^{-1} \mathrm{FW}\right)\end{array}$} & \multicolumn{2}{|c|}{$\begin{array}{l}\text { Antioxidant } \\
\text { Activity (\%) }\end{array}$} \\
\hline & 2014 & 2015 & 2014 & 2015 & 2014 & 2015 & 2014 & 2015 & 2014 & 2015 & 2014 & 2015 \\
\hline Control & $16.3^{b}$ & $16.8^{c}$ & $1.82^{\mathrm{a}}$ & $1.74^{\mathrm{a}}$ & $8.95^{c}$ & $9.65^{\mathrm{d}}$ & $14.32^{b}$ & $14.18^{b}$ & $409.13^{a}$ & $405.05^{a}$ & $24.23^{\mathrm{a}}$ & $24.02^{a}$ \\
\hline $\mathrm{nFe} 1$ & $17.5^{\mathrm{ab}}$ & $17.6^{\mathrm{abc}}$ & $1.73^{a}$ & $1.64^{\mathrm{a}}$ & $10.11^{b}$ & $10.72^{b}$ & $15.17^{\mathrm{a}}$ & $15.11^{\mathrm{a}}$ & $406.28^{b c}$ & $402.67^{b}$ & $23.23^{a b}$ & $23.44^{\mathrm{ab}}$ \\
\hline $\mathrm{nFe} 2$ & $17.9^{\mathrm{a}}$ & $18.0^{\mathrm{a}}$ & $1.51^{\mathrm{b}}$ & $1.54^{\mathrm{b}}$ & $11.87^{a}$ & $11.70^{\mathrm{a}}$ & $15.20^{\mathrm{a}}$ & $15.15^{a}$ & $404.94^{\mathrm{c}}$ & $402.60^{b}$ & $22.54^{b}$ & $22.19^{b}$ \\
\hline cFe1 & $16.5^{b}$ & $17.0^{\mathrm{bc}}$ & $1.76^{\mathrm{a}}$ & $1.72^{\mathrm{a}}$ & $9.35^{b c}$ & $9.88^{\mathrm{cd}}$ & $14.34^{\mathrm{b}}$ & $14.21^{\mathrm{b}}$ & $408.28^{a b}$ & $404.82^{\mathrm{a}}$ & $24.13^{a}$ & $23.89^{a}$ \\
\hline $\mathrm{cFe} 2$ & $16.7^{b}$ & $17.7^{\mathrm{ab}}$ & $1.75^{\mathrm{a}}$ & $1.68^{a}$ & $9.55^{b c}$ & $10.54^{b c}$ & $14.84^{\mathrm{ab}}$ & $14.85^{\mathrm{ab}}$ & $407.25^{a b c}$ & $402.79^{b}$ & $23.96^{\mathrm{a}}$ & $22.29^{b}$ \\
\hline
\end{tabular}

$\mathrm{FeSO}_{4}$ was used at rates of $72(\mathrm{nF} 1)$ and $144(\mathrm{nF} 2) \mathrm{mg} \mathrm{Fe} \mathrm{L}^{-1}$ and Fe(III)-EDDHA was used at rates of 60 (cF1) and 120 (cF2) mg Fe L ${ }^{-1}$. In each column, means followed by the same letter were not significantly different $(p<0.05)$ 
The only foliar treatments that caused changes in sugars in fruit juice were those with $\mathrm{FeSO}_{4}$, which significantly increased total sugars (by 6-7\%; Table 2). The highest amounts of total sugars

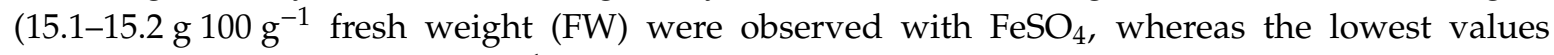

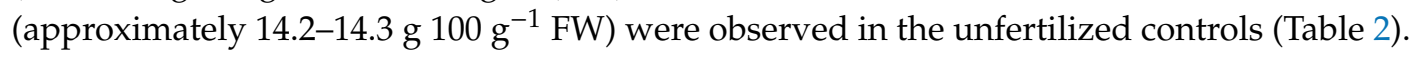

Foliar Fe fertilization decreased slightly total phenolics (by $1 \%$; with both $\mathrm{FeSO}_{4}$ doses in both seasons and in the high chelate dose in 2015) and antioxidant activity (7-8\%; with $2.6 \mathrm{mM} \mathrm{FeSO}_{4}$ in both seasons and $2.1 \mathrm{mM}$ chelate in 2015) in pomegranate fruit juice (Table 2). However, total anthocyanin contents did not show significant changes (Table S3 in the Supplementary File).

\section{Discussion}

Foliar Fe fertilization in pomegranate led to consistent increases in leaf Fe concentrations, as it has been shown to occur in many fruit crops, including peach [8] and orange $[23,24]$. Leaf concentrations found in pomegranate trees (108-118 $\left.\mathrm{mg} \mathrm{Fe} \mathrm{kg}^{-1} \mathrm{DW}\right)$ are in line with values reported previously in pomegranate field orchards in Iran (127-130 $\left.\mathrm{mg} \mathrm{Fe} \mathrm{kg}^{-1} \mathrm{DW}\right)$ [21,25]. Relatively large Fe concentrations (above $100 \mathrm{mg} \mathrm{Fe} \mathrm{kg}^{-1} \mathrm{DW}$, sometimes even higher than those in green leaves) are often observed in Fe-deficient, chlorotic leaves in other fruit tree species grown in calcareous soils, in what has been denominated "Fe chlorosis paradox" [26], and this is likely to be due to precipitation of Fe in the leaf apoplast or the xylem in chemical forms that are physiologically unavailable $[27,28]$. The fact that Fe foliar fertilization is capable of increasing fruit set and yield supports that the Fe chlorosis paradox also occurs in pomegranate. Conversely, foliar fertilization with Fe compounds did not change the concentrations of other leaf nutrients, confirming that this depends on the specific crop and other factors. For instance, foliar Fe fertilization in peach trees did not affect significantly leaf $\mathrm{P}, \mathrm{K}, \mathrm{Mg}$, $\mathrm{Cu}$ and $\mathrm{Zn}$ concentrations [8], whereas increases in $\mathrm{K}$ and $\mathrm{Ca}$ and decreases in $\mathrm{N}, \mathrm{P}, \mathrm{Mg}, \mathrm{Mn}, \mathrm{Zn}$ and $\mathrm{Cu}$ were found in orange trees [23].

Foliar Fe fertilization in pomegranate caused increases in yield, confirming results from a previous study, where foliar Fe sprays at full bloom and approximately one month thereafter increased yield significantly [29]. These results support the addition of Fe to the list of elements ( $\mathrm{Zn}, \mathrm{B}$ and N) [14-16] that when applied to the foliage in the early season promote fruit set in pomegranate trees, thereby improving the income of pomegranate growers. Results observed here are in line with studies indicating that foliar fertilization with Fe led to fruit yield increases in citrus [30-32].

The increases in yield observed here were associated with increases in number of fruits per plant. Such association has been also observed in peach [33], and the leaf chlorophyll concentration was found to correlate with the number of fruits per tree both in peach and pear [34]. Iron deficiency has been reported to hamper fruit set in other plant species. For instance, an increase in the percentage of flowers lacking ovaries has been found in Fe-deficient olive trees [35], and foliar Fe fertilization led to increases in the number of flowers, fruit set and yield in strawberry [36]. Iron is required to build thylakoid membranes in the chloroplast and therefore, Fe deficiency causes decreases in leaf chlorophyll, electron transport capacity and photosynthesis. Therefore, a sustained Fe deficiency can affect flowering and fruit set due to carbohydrate depletion resulting from marked decreases in photosynthetic rates in chlorotic leaves.

The effects of early season Fe foliar fertilization on the number of fruits support that the applied $\mathrm{Fe}$ is rapidly incorporated into developing reproductive organs, in turn leading to an increase in the number of flowers resulting in fruits. This suggests that the nutrient transport systems existing in pomegranate flowers are capable of using exogenous $\mathrm{Fe}$, especially when supplied as Fe(II). In leaves, inorganic Fe has been proposed to enter plants via stomata and move throughout the plant via phloem tissues [37], but to the best of our knowledge no information exists on the mechanisms for Fe entry into flowers or developing fruits so far. In contrast to the rapid Fe incorporation observed here, when Fe(III)-chelates were applied to the soil at the flowering stage in peach trees, no effect was observed on flower Fe concentration, probably due to the low xylem activity in that period [38]. 
Foliar fertilization with $2.6 \mathrm{mM} \mathrm{FeSO}_{4}$ had an effect on pomegranate aril juice as well as on juice TSS, TA and sugar content. Iron fertilization effects on fruit juice have been also observed in other fruit crops. In citrus, increases in fruit juice upon Fe fertilization have been interpreted as a result of a better plant nutrition, associated with increases in cell turgor pressure and water and mineral absorption [24,39]. Increases in TSS with Fe fertilization were also found in pomegranate [29] and strawberry [36], and the application of Fe-chelate at full bloom and after fruit set significantly decreased TA in peach juice [39]. Foliar sprays with different Fe sources, including Fe-EDDHA and $\mathrm{FeSO}_{4}$, also led to increases in TSS and decreases in TA and therefore maturity index in citrus fruits $[23,24,39]$. Applications of Fe foliar fertilizers increased non-reducing and total sugars in date palm [40]. The increase in TSS and total sugars upon Fe fertilization can be attributed to the role of Fe in chlorophyll and thylakoid synthesis and chloroplast development as well as the ability of Fe to act as a cofactor for many enzymes [5]. Foliar Fe fertilization leads to increases in photosynthesis rates and carbohydrate contents $[8,33]$.

Foliar fertilization had only minor effects on the antioxidant activity and phenolic compound content in fruit juice. The relatively high phenolic compound contents observed here are within the

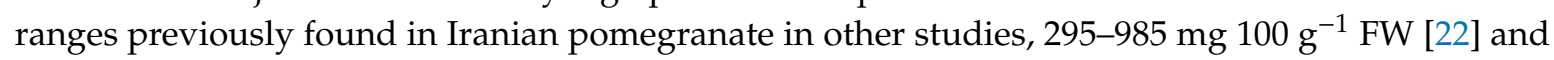
526-797 mg $100 \mathrm{~g}^{-1} \mathrm{FW}$ [41]. The accumulation of secondary metabolites, such as phenolic compounds, is often a symptom of defense responses of plants to stress [42-44]. It has been reported that the production of health-promoting compounds can increase in Fe-deficient plants, including increases in phenolics in peach $[33,34]$.

\section{Conclusions}

Results indicated that early season Fe foliar sprays, applied at full bloom and one month thereafter, led to significant increases in the number of fruits per tree and fruit yield. This revealed a marked effect of Fe fertilization on fruit set, although somewhat smaller than those found previously with $\mathrm{Zn}$, $\mathrm{B}$ and $\mathrm{N}$ at the same developmental stage [14-16]. The increase in yield was also accompanied by a small, but significant, change in fruit quality, with increases in aril juice, TSS, maturity index and total sugars and less intense changes in TA and antioxidant activity. With regard to the efficiency of the two different $\mathrm{Fe}$ products used, $\mathrm{FeSO}_{4}$ was better than $\mathrm{Fe}(\mathrm{III})$-EDDHA, although the Fe doses used were $24 \%$ higher in the former product. Future experiments should be carried out to unravel the nature of Fe transporters in flowers and to explore the possible efficiency of complex foliar fertilizers, which may include $\mathrm{Zn}, \mathrm{B}, \mathrm{N}$ and $\mathrm{Fe}$, to improve the quality and yield of pomegranate orchards grown in poor soils.

Supplementary Materials: The following are available online at http://www.mdpi.com/2073-4395/10/6/832/s1. Figure S1: Orchard of Punica granatum L. cv. Ardestani used in the study. Figure S2: Scanning electron microscopy-dispersive X-ray analysis (SEM-EDX) of the particles in the $\mathrm{FeSO}_{4}$ fertilizer. Table S1: Effect of foliar fertilization with $\mathrm{FeSO}_{4}(\mathrm{nFe})$ and $\mathrm{Fe}(\mathrm{III})$-EDDHA (cFe) fertilizers on pomegranate leaf N, P, K, Ca, Mn and Zn concentrations in 2014 and 2015. Table S2: Effect of foliar fertilization with $\mathrm{FeSO}_{4}$ (nFe) and Fe(III)-EDDHA (cFe) fertilizers on pomegranate fruit weight, fruit length, fruit diameter, fruit cracking and weight of 100 arils in 2014 and 2015. Table S3: Effect of foliar fertilization with $\mathrm{FeSO}_{4}$ (nFe) and Fe(III)-EDDHA (cFe) fertilizers on pomegranate aril and peel percentage, aril/peel ratio, peel thickness, calyx diameter and total anthocyanins in 2014 and 2015.

Author Contributions: Design of the experiment and methodology, S.D. and A.T.; data analysis, S.D., A.T. and J.A.; writing—original draft preparation, S.D., M.Z., M.A. and G.D.; writing—review and editing, S.D., A.T. and J.A.; supervision and project administration, A.T.; and funding acquisition, A.T. and J.A. All authors have read and agree to the published version of the manuscript.

Funding: The study was funded by the Ferdowsi University of Mashhad (code: 3/32199). J.A. was partially supported by the Spanish State Research Agency (AEI) co-financed by the European Regional Development Fund (FEDER) (project AGL2016-75226-R; AEI/FEDER, UE) and the Aragón Government (group A09-20R).

Acknowledgments: Thanks are given to the managing director of the Tous Dasht orchard for support, M. Palancar and M.C. Lope (EEAD-CSIC) for mineral analysis, and I. Tacchini and J.M Andrés (Instituto de Carboquímica, ICB-CSIC) for SEM-EDX analysis and use of equipment, respectively.

Conflicts of Interest: The authors declare no conflict of interest. 


\section{References}

1. Holland, D.; Hatib, K.; Bar-Ya'akov, I. Pomegranate: Botany, horticulture, breeding. Hortic. Rev. 2009, 35 , 127-191.

2. Anonymous. Iran Statistical Year Book, 1st ed.; Ministry of Agriculture-Jahad: Tehran, Iran, 2016; ISBN 978-964-467-082-4. Available online: http://www.maj.ir/Dorsapax/userfiles/Sub65/amarnamehj3-95.pdf (accessed on 24 April 2020).

3. Legua, P.; Melgarejo, P.; Abdelmajid, H.; Martínez, J.J.; Martínez, R.; Ilham, H.; Hafida, H.; Hernández, F. Total phenols and antioxidant capacity in 10 Moroccan pomegranate varieties. J. Food Sci. 2012, 71, 115-120. [CrossRef]

4. Jackson, L.K.; Alva, A.K.; Tucker, D.P.H.; Calvert, D.V. Factors to consider in developing a nutrition program. In Nutrition of Florida Citrus Trees, 3rd ed.; Tucker, D.P.H., Alva, A.K., Jackson, L.K., Wheaton, T.A., Eds.; IFAS University Florida: Gainesville, FL, USA, 1995; pp. 3-11.

5. Marschner, H. Mineral. Nutrition of Higher Plants; Academic Press Limited., Harcourt Brace and Company Publishers: London, UK, 2012.

6. Fernández, V.; Sotiropoulos, T.; Brown, P.H. Foliar Fertilization: Scientific Principles and Field Practices, 1st ed.; International Fertilizer Industry Association: Paris, France, 2013; ISBN 979-10-92366-00-6.

7. Aciksoz, S.B.; Yazici, A.; Ozturk, L.; Cakmak, I. Biofortification of wheat with iron through soil and foliar application of nitrogen and iron fertilizers. Plant Soil 2011, 349, 215-225. [CrossRef]

8. El-Jendoubi, H.; Vázquez, S.; Calatayud, A.; Vavpetic, P.; Vogel-Mikuš, K.; Pelicon, P.; Abadía, J.; Abadía, A.; Morales, F. The effects of foliar fertilization with iron sulfate in chlorotic leaves are limited to the treated area. A study with peach trees (Prunus persica L. Batsch) grown in the field and sugar beet (Beta vulgaris L.) grown in hydroponics. Front. Plant Sci. 2014, 5, 2. [CrossRef] [PubMed]

9. Lindsay, W.L.; Schwab, A.P. The chemistry of iron in soil and its availability to plants. J. Plant Nutr. 1982, 4, 821-840. [CrossRef]

10. Abadía, J.; Vázquez, S.; Rellán-Alvarez, R.; El-Jendoubi, H.; Abadía, A.; Álvarez-Fernández, A.; López-Millán, A.F. Towards a knowledge-based correction of iron chlorosis. Plant. Physiol. Biochem. 2011, 49, 471-482. [CrossRef] [PubMed]

11. López-Rayo, S.; Nadal, P.; Lucena, J.J. Reactivity and effectiveness of traditional and novel ligands for multi-micronutrient fertilization in a calcareous soil. Front. Plant Sci. 2015, 6, 752. [CrossRef] [PubMed]

12. El-Jendoubi, H.; Melgar, J.C.; Álvarez-Fernández, A.; Sanz, M.; Abadía, A.; Abadía, J. Setting good practices to assess the efficiency of iron fertilizers. Plant Physiol. Biochem. 2011, 49, 483-488. [CrossRef]

13. Larbi, A.; Morales, F.; Abadía, J.; Abadía, A. Effect of branch solid Fe implants on Fe xylem transport in peach and pear: Changes in organic acid and Fe concentrations and pH. J. Plant Physiol. 2003, 160, 1473-1482. [CrossRef]

14. Davarpanah, S.; Tehranifar, A.; Davarynejad, G.; Abadía, J.; Khorasani, R. Effects of foliar applications of zinc and boron nano-fertilisers on pomegranate (Punica granatum cv. Ardestani) fruit yield and quality. Sci. Hortic. 2016, 210, 57-64.

15. Davarpanah, S.; Tehranifar, A.; Davarynejad, G.; Aran, M.; Abadía, J.; Khorasani, R. Effects of Foliar nano-nitrogen and urea fertilizers on the physical and chemical properties of pomegranate (Punica granatum cv. Ardestani) fruits. Hortscience 2017, 52, 288-294. [CrossRef]

16. Davarpanah, S.; Tehranifar, A.; Abadía, J.; Val, J.; Davarynejad, G.; Aran, M.; Khorassani, R. Foliar calcium fertilization reduces fruit cracking in pomegranate (Punica granatum cv. Ardestani). Sci. Hortic. 2018, 230, 86-91. [CrossRef]

17. Wetzstein, H.Y.; Ravid, N.; Wilkins, E.; Pinheiro-Martinelli, A. A morphological and histological characterization of bisexual and male flower types in pomegranate. J. Am. Soc. Hortic. Sci. 2011, 136, 83-92. [CrossRef]

18. Ben-Arie, R.; Segal, N.; Guelfat-Reich, S. The maturation and ripening of the 'Wonderful' pomegranate. J. Am. Soc. Hort. Sci. 1984, 109, 898-902.

19. Chapman, H.D.; Pratt, P.F. Methods of Analysis for Soils, Plants and Water, 1st ed.; University of California: Berkeley, CA, USA, 1961. 
20. Carrasco-Gil, S.; Rios, J.J.; Álvarez-Fernández, A.; Abadía, A.; García-Mina, J.M.; Abadía, J. Effects of individual and combined metal foliar fertilisers on iron- and manganese-deficient Solanum lycopersicum plants. Plant Soil 2016, 402, 27-45. [CrossRef]

21. Hasani, M.; Zamani, Z.; Savaghebi, G.; Fatahi, R. Effects of zinc and manganese as foliar spray on pomegranate yield, fruit quality and leaf minerals. J. Soil Sci. Plant Nutr. 2012, 12, 471-480. [CrossRef]

22. Tehranifar, A.; Zarei, M.; Nemati, Z.; Esfandiyari, B.; Vazifeshenas, M.R. Investigation of physico-chemical properties and antioxidant activity of twenty Iranian pomegranate (Punica granatum L.) cultivars. Sci. Hortic. 2010, 126, 180-185. [CrossRef]

23. El-Shazly, S.M.; Abdel Naseer, G.; Harhsh, M.M. Physiological and biochemical indices in Washington novel orange trees as influenced by iron foliar application. Alex. J. Agric. Res. 2000, 45, 287-306.

24. Amri, E.; Shahsavar, A.R. Comparative efficacy of citric acid and Fe(II) sulfate in the prevention of chlorosis in orange trees (Citrus sinensis L. cv. Darabi). J. Biol. Environ. Sci. 2009, 3, 61-65.

25. Hasani, M.; Zamani, Z.; Savaghebi, G.; Sheikh Sofla, H. Effect of foliar and soil application of urea on leaf nutrients concentrations, yield and fruit quality of pomegranate. J. Plant Nutr. 2016, 39, 749-755. [CrossRef]

26. Morales, F.; Grasa, R.; Abadía, A.; Abadía, J. The iron "chlorosis paradox" in fruit trees. J. Plant Nutr. 1998, 21, 815-825. [CrossRef]

27. Mengel, K.; Geurtzen, G. Relationship between iron chlorosis and alkalinity in Zea mays. Physiol. Plant. 1988, 72, 460-465. [CrossRef]

28. Jiménez, S.; Morales, F.; Abadía, A.; Abadía, J.; Moreno, M.A.; Gogorcena, Y. Elemental 2-D mapping and changes in leaf iron and chlorophyll in response to iron re-supply in iron-deficient GF 677 peach-almond hybrid. Plant Soil 2009, 315, 93-106. [CrossRef]

29. Zareh, M.; Adhami, E.; Owliaie, H.; Ramezanian, A. Effects of foliar applications of iron and zinc on yield, fruit quantitative and qualitative characteristics and mineral composition of pomegranate (Punica granatum L.) leaf. Iran. Hortic. Sci. Technol. 2012, 13, 189-198. (In Persian)

30. Aboutalebi, A. Effects of nitrogen and iron on sweet lime (Citrus limmetta) fruit quantity and quality in calcareous soils. J. Novel Appl. Sci. 2013, 2, 211-213.

31. Chen, F.; Lu, J. Effect of iron chelate application on citrus in the three gorges area. Better Crops 2006, 90, 33-35.

32. Jahanshah, S. Effects of different methods of iron application on yield and leaf and fruit chemical compositions of 'Lisbon' lemon cultivar. J. Hortic. Sci. Technol. 2009, 9, 23-34. (In Persian)

33. Álvarez-Fernández, A.; Paniagua, P.; Abadía, J.; Abadía, A. Effects of Fe deficiency chlorosis on yield and fruit quality in peach (Prunus persica L. Batsch). J. Agric. Food Chem. 2003, 51, 5738-5744. [CrossRef] [PubMed]

34. Álvarez-Fernández, A.; Melgar, J.C.; Abadía, J.; Abadía, A. Effects of moderate and severe iron deficiency chlorosis on fruit yield, appearance and composition in pear (Pyrus communis L.) and peach (Prunus persica L. Batsch). Environ. Exp. Bot. 2011, 71, 280-286. [CrossRef]

35. Pastor, M.; Castro, J.; Hidalgo, J. Corrección de la clorosis férrica en olivar en zonas afectadas. Vida Rural 2001, 129, 42-44.

36. Chaturvedi, O.P.; Singh, A.K.; Tripathi, V.K.; Dixit, A.K. Effect of zinc and iron on growth, yield and quality of strawberry cv. Chandler. Acta Hortic. 2005, 696, 237-240. [CrossRef]

37. Rios, J.J.; Carrasco-Gil, S.; Abadía, A.; Abadía, J. Using Perls staining to trace the iron uptake pathway in leaves of a Prunus rootstock treated with iron foliar fertilizers. Front. Plant Sci. 2016, 7, 893. [CrossRef] [PubMed]

38. Abadía, J.; Tagliavini, M.; Grasa, R.; Belkhodja, R.; Abadía, A.; Sanz, M.; Faria, E.A.; Tsipouridis, C.; Marangoni, B. Using the flower Fe concentration for estimating crop chlorosis status in fruit tree orchards. A summary report. J. Plant Nutr. 2000, 23, 2023-2033. [CrossRef]

39. Pestana, M.; Correia, P.J.; de Varennes, A.; Abadía, J.; Faria, E.A. Effectiveness of different foliar iron applications to control iron chlorosis in orange trees grown on a calcareous soil. J. Plant Nutr. 2001, 24, 613-622. [CrossRef]

40. Abdi, G.; Hedayat, M. Yield and fruit physiochemical characteristic of kabkab date palm as affected by methods of iron fertilization. World Appl. Sci. J. 2010, 10, 1328-1333.

41. Zarei, M.; Azizi, M.; Bashiri-Sadr, Z. Studies on physico-chemical properties and bioactive compounds of six pomegranate cultivars grown in Iran. J. Food Technol. 2010, 8, 112-117. [CrossRef]

42. Chisaki, N.; Horiguchi, T. Responses of secondary metabolism in plants to nutrient deficiency. Soil Sci. Plant Nutr. 1997, 43, 987-991. [CrossRef] 
43. Weisskopf, L.; Tomasi, N.; Santelia, D.; Martinoia, E.; Langlade, N.B.; Tabacchi, R.; Abou-Mansour, E. Isoflavonoid exudation from white lupin roots is influenced by phosphate supply, root type and cluster-root stage. New Phytol. 2006, 171, 657-668. [CrossRef]

44. Kovacik, J.; Klejdus, B.; Backor, M.; Repcak, M. Phenylalanine ammonia-lyase activity and phenolic compounds accumulation in nitrogen-deficient Matricaria chamomilla leaf rosettes. Plant Sci. 2007, 172, 393-399. [CrossRef]

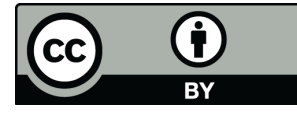

(C) 2020 by the authors. Licensee MDPI, Basel, Switzerland. This article is an open access article distributed under the terms and conditions of the Creative Commons Attribution (CC BY) license (http://creativecommons.org/licenses/by/4.0/). 